\title{
FRECUENCIA DE LA INFECCIÓN POR VIRUS DE LA HEPATITIS C EN PACIENTES CON CIRROSIS HEPÁTICA EN YUCATÁN.
}

Yeh Gorocica Aaron B ${ }^{1}$, Adolfo Palma Chan ${ }^{2}$, Noh Pech Henry R ${ }^{1}$, Avila Padilla Diana C1, López Avila Karina B ${ }^{1}$, Tello Martín Raul A ${ }^{1}$, Lugo Caballero Cesar ${ }^{1}$, Dzul Rosado Karla $^{1}$, Zavala Castro Jorge ${ }^{1}$, Puerto Fernando I ${ }^{1}$.

${ }^{1}$ Centro de Investigaciones Regionales "Dr. Hideyo Noguchi”

${ }^{2}$ Hospital General Agustín O’Horán.

Contacto: Aaron B. Yeh Gorocica; aaron.yeh@uady.com; ayega17@gmail.com

\section{Resumen}

Introducción. La hepatitis C es causada por el virus de la hepatitis C (VHC), la

Organización Mundial de la Salud estima 170 millones de personas se encuentran infectadas por el virus. El 80\% de los infectados no elimina el virus de manera natural volviéndose crónico y llevando al desarrollo de cirrosis hepática en el 20\% de los casos y carcinoma hepatocelular en el 10\%. México se estima una seroprevalencia de 1.5\% en la población general, y en Yucatán de 1.6\%. En pacientes con cirrosis hepática se estima 32\% en el Estado. Objetivo. Detectar la presencia de la infección activa de los VHC en los pacientes con cirrosis hepática que son atendidos en el Hospital General “Dr. Agustín O’Horán” de Mérida Yucatán. Metodología. Se tomaron 62 muestras séricas, se realizó la extracción de ARN total seguido de la síntesis de ADNc, la amplificación de la región 5' no codificante de los VHC con la técnica de reacción en cadena de la polimerasa, obteniendo un amplicon de 144 pares de bases. Resultado y Conclusión. 46.16\% de las muestras séricas de los pacientes presentaron genoma viral circulante; hubo un aumento de la cirrosis causada por el VHC en un periodo de 10 años. 


\section{Introducción}

La Hepatitis C es causada por el virus de la hepatitis C (VHC), al día de hoy la Organización Mundial de la Salud estima que aproximadamente 170 millones de personas se encuentran infectadas por el virus y al año se estiman 350,000 muertas asociadas a la infección por VHC1․ De las personas que se infectan aproximadamente el 80\% no logra eliminar el virus de manera natural por lo que la infección se vuelve crónica, esta cronicidad conlleva al desarrollo de enfermedades hepáticas crónicas asociadas con el desarrollo de cirrosis hepática en el 20\% y carcinoma hepatocelular en el $10 \%$ de las personas infectadas con el VHC.

En México se ha estimado una prevalencia media nacional de $1.5 \%$, dependiendo de la región esta puede variar de 0.81\% a 1.65\%; en Yucatán se estima una prevalencia de $1.6 \%$ en la población en general, en donadores de sangre una seroprevalencia de $1.25 \%$ y pacientes con cirrosis hepática de $32 \% .^{2-5}$

Por lo que el objetivo del presente trabajo es detectar la presencia de la infección activa de los VHC en los pacientes con cirrosis hepática que son atendidos en el Hospital General “Dr. Agustín O’Horán” de Mérida Yucatán.

\section{Materiales}

Se tomaron 62 muestras séricas de pacientes diagnosticados con cirrosis hepática que fueron atendidos en el Hospital General “Dr. Agustín O’Horán”. Se realizó la extracción del material genómico con el reactivo comercial Trizol Reagent (Life Technologies) siguiendo las indicaciones del proveedor. La síntesis de DNA complementario se realizó con el reactivo comercial Improm II Reverse Transcription System Kit (Promega) siguiendo las indicaciones del proveedor. La reacción en cadena 
de la polimerasa (PCR) se realizó empleando los cebadores descritos por Okamoto y colaboradores en 1990 dirigidos a la región 5’ $\mathrm{NC}$ de los $\mathrm{VHC}^{6}$. Las condiciones finales de la reacción de PCR fueron: 1x PCR Buffer, 0.08 mM de dNTPs, 2 mM de $\mathrm{MgCl}$, 0.2 $\mu \mathrm{M}$ de cebadores para ambas PCR, Taq Polimerasa equivalente a 1 unidad y c.b.p. 25

$\mu \mathrm{l}$ de agua DEPC; bajo las siguientes condiciones de temperatura: un ciclo de desnaturalización a $95^{\circ} \mathrm{C}$ durante 5 minutos; seguido de 40 ciclos a $94^{\circ} \mathrm{C}$ durante 1 minuto, $52^{\circ} \mathrm{C}$ durante 30 segundos y $72^{\circ} \mathrm{C}$ durante 1 minuto; al final de ciclo 40 continua con 1 ciclo a $72^{\circ} \mathrm{C}$ durante 10 minutos; finalmente se almacenó a $-20^{\circ} \mathrm{C}$ la reacción, obteniendo al final un amplificado de 144 pares de bases.

\section{Resultados y Discusión.}

El $45.16 \%$ de las muestras séricas de los pacientes con cirrosis hepática (28/62) presentaron genoma viral circulante, sin embargo algunos de estos pacientes (datos no presentados) aún no se les realiza la detección de anticuerpos contra VHC por lo que no conocen su condición serológica.; por lo que estos pacientes son de alto riesgo para la transmisión del virus. Por lo que podríamos inferir una seroprevalencia mayor al 32\% ${ }^{4}$ reportado previamente en Yucatán, debido a que la proporción de infección activa de los VHC: serología positiva contra los VHC es 1:3 aproximadamente en la población en general ${ }^{7}$.

\section{Conclusión.}

Este resultado nos demuestra que hubo un aumento de la cirrosis causada por el VHC, cambió que se llevó a cabo en un período de 10 años. También se puede 
explicar porque las pruebas serológicas de hace 10 años no eran tan eficientes como las de ahora. Es necesario una intervención de la SSY para diagnosticar y tratar esta infección, dado que son en realidad pocas las personas con infección. Así se disminuiría la incidencia de cirrosis hepática causada por el VHC y mantener un sistema de vigilancia epidemiológica para detectar la infección viral activa, debido al alto riesgo que presenta para la transmisión de los VHC a la población en general.

\section{Bibliografía}

1. World Health Organization. Hepatitis C. 2013. Available at:

2. Burguete-García A, Conde-Gonzalez C, Jimenez-Mendez R, et al. Hepatitis C seroprevalence and correlation between viral load and viral genotype among primary care clients in Mexico. Salud Publica Mex. 2011;53(1):7-12.

3. Fundacion Mexicana para la Salud Hepática. Hepatitis $C$ as a public health problem in Mexico. Salud Publica Mex. 2011;53(1):61-67.

4. Góngora-Biachi R a, Castro-Sansores CJ, González-Martínez P, Lara-Perera DM, Garrido-Palma J, Lara-Perera V. Frequency of antibodies against the hepatitis C virus in patients with hepatic cirrhosis in Yucatan, Mexico. Salud Publica Mex. 2003;45(5):346-50.

5. Góngora-Biachi R, González-Martínez P, Puerto F, Yamaguchi K, Nishimura Y, Takatsuki K. Antibodies to hepatitis C virus in people from Yucatan. Rev Investagacion Clin. 1992;44(2):284.

6. Okamoto H, Okada S, Sugiyama Y, et al. Detection of hepatitis C virus RNA by a two-stage polymerase chain reaction with two pairs of primers deduced from the 5'-noncoding region. Jpn J Exp Med. 1990;60(4):215-222.

7. Valdespino JL, Conde-González CJ, Olaiz-Fernández G, Palma O, Kershenobich D, Sepúlveda J. Seroprevalencia de la hepatitis $\mathrm{C}$ en adultos de México: ¿un problema de salud pública emergente? Salud Publica Mex. 2007;49:s395-s403. 